\section{The "Subprime" Market and International Higher Education}

\section{Philip G. Altbach}

Philip G. Altbach is Monan professor of higher education and director of the Center for International Higher Education at Boston College

I t may be illuminating to compare the current subprime 1 mortgage and housing-sector crisis in the United States and developments in international higher education. First, buyers and the housing and financial industries wanted to participate in a growing and lucrative housing market, just as many groups in the higher education industry now want to be players in international higher education. Housing prices were rising fast, and not many questions were asked about products, sellers, or buyers. This market was allowed to function without constraint. Then, a certain "irrational exuberance" set in, with the market becoming saturated and many speculators entering -in a way, a "bubble" mentality. Some buyers wanted to make a quick profit while others failed to recognize the risks of the new loans. Financial institutions got caught up and invented ever more complicated loan structures to spread risk globally. There was soon a growing recognition of the problems with the overheated housing and mortgage markets-inadequate supervision, oversupply of products, unsustainable costs, unfulfillable promises, and other challenges. In the mortgage/housing environment, the bubble has burst and many countries face very serious economic and social consequences. It is also noteworthy that the mortgage and housing crisis started in the largest market, the United States, and is spreading worldwide.

International higher education stands somewhere in the middle of the cycle-somewhere between irrational exuberance and a bubble. Now is the time to look at what actions are sustainable and what are not, what policy will serve the interests of students and the academic community, and what actions constitute mistaken policy or simple greed.

The academic community is committed to internationalization, although motivations differ and some institutions have no clear idea why they are involved. A recent survey by the International Association of Universities of academic leaders worldwide shows a huge variation of motivations, ranging from more internationally oriented students and staff, curricular improvement, building a "name brand," global collaboration, providing opportunities for research, and many others. Curiously, only a small minority of academic leaders cited earning income from international initiatives-an especially surprising point of view given that the Australian and British governments have emphasized earning money as a key goal of internationalization. University presidents, vice chancellors, and rectors from Europe and North America have been trooping to China and India prospecting for international busi- ness-such as, branch campuses, collaborative linkages, and joint-degree arrangements.

\section{THE LANDSCAPE}

We know a few things about the international higher education landscape. There are perhaps 3 million students studying outside their own countries-with the most from from Asiawith the largest number matriculating in the major Englishspeaking academic powers. An Australian study estimated that there will be 8 million international students by 2025 , since cross-border study continues to be big business. No one knows how many branch campuses exist, but estimates are in the many hundreds-almost all of them located in developing or middle-income countries. The growth of "American University of ... (fill in the blank)" is rapid as well. In addition to old and respected American-linked universities in Cairo and Beirut, institutions using the term "American" and often teaching in English are proliferating throughout the developing world, joined recently by institutions with "German," "French," or "Canadian" in their names. The expansion of academic offerings in English worldwide has created a new market for programs and for professorial mobility. The global higher education marketplace is large, growing, and basically unregulated. It is indeed the "Wild West" or, more appropriately, the "Wild East."

\section{The Problems}

In higher education, one might take the view that "the market will sort itself out" and thus leave hands off. Here again the subprime mortgage crisis represents a certain analogy regarding higher education. By permitting unscrupulous players to perform and by encouraging more respectable banks to buy up risky debt without much regulation or restriction, the world has reached today's crisis. The financial instruments being used are very complex, and institutions worldwide have purchased them, reducing whatever accountability might have previously existed.

There is a similar mentality in the world of international higher education. Everyone can get into the market for international higher education. Sellers, including academic institutions and for-profit education providers, can easily enter the global market by selling educational products and services in a largely unregulated marketplace. Some of the sellers are prestigious universities hoping to build links overseas, recruit top students to their home campuses, and strengthen their name brands in the world market. Many of the sellers are themselves

\section{Erratum}

Our last issue, Number 50, was labeled as Winter 2007. It is actually the Winter 2008 issue. We regret any misunderstanding. 
subprime institutions-sleazy recruiters, degree packagers, low-end private institutions seeking to stave off bankruptcy through the export market and even a few respectable universities forced by government funding cutbacks to enter foreign markets for profit making.

Buyers, such as students but also including some academic institutions in developing countries, are similarly unregulated, sometimes ill-informed and often naive. Most tragically, students and their families buy international educational services without much information or understanding. Sometimes recruited to study abroad at subprime schools or motivated more by the desire to seek employment than to study, students may be shortchanged. Uninformed or simply avaricious institutions in developing countries may partner with low-quality colleges and universities in, for example, the United States, Australia, the United Kingdom and receive substandard teaching or degree courses. Regulatory agencies may be entirely missing or inappropriate, thus making quality assurance impossible to achieve. There are not enough top-quality universities in countries like China and India to absorb all of the potential overseas partners. Further, most academic institutions worldwide lack the infrastructures to successfully engage in sophisticated international programs and initiatives.

\section{How to Avoid a CRISIS}

Transparency is a key step for building a healthy international higher education environment. This approach means obtaining accurate information about the scope and extent of international higher education-by governments, international and regional organizations, and by universities. Information about motives and policies would also be useful, although now very little reliable information is available. The market should not be left to determine the success or failure of international high-

International higher education stands somewhere in the middle of the cycle-somewhere between irrational exuberance and a bubble.

er education. Some interests, especially the governments of the major "sellers" (such as the United States, Australia, and the United Kingdom and the for-profit education industry) argue that the doors to international commerce in higher education should be open and that this openness should be legislated by the World Trade Organization through the General Agreement on Trade in Services. Such forced openness would leave the world subject to whatever irrational exuberance and bubble mentality that is now evident in the mortgage industry and is increasingly in higher education.

The world also needs clear regulation, probably by government authority, to ensure that national interests are served and students and their families are not subjected to shoddy business practices by unscrupulous education providers. This will also help academic institutions themselves think about their motivations for entry into the global education market. Internationalization, including student mobility, cross-border educational provision, and involvement in the global knowledge economy of the 2Ist century is a positive and inevitable element of global higher education. What academe needs to avoid is succumbing to subprime practices and the inevitable crisis that will ensue.

(This article was published in Times Higher Education, London.)

\section{Foreign-Backed Universities: A New Trend}

\section{UTE LANZENDORF}

Ute Lanzendorf is researcher and manager at the International Center for Higher Education Research, University of Kassel, Germany. E-mail: ulanzend@incher.uni-kassel.de.

Tn the last decade, discussions about transnational universiI ties concentrated on the branch campus model. In recent years, another type of transnational institutions has expanded rapidly: the foreign-backed university.

\section{Beyond Branch Campuses}

In contrast to a branch campus, a foreign-backed university is set up not by a foreign academic institution but rather by (wealthy) local individuals, local governments, or enterprises. The local founders provide or organize the basic financial endowment for a new university but also delegate academic development to one or several "academic mentor" or "patron" universities abroad. Thus, foreign-backed institutions are legally independent local universities that are academically affiliated with one or several universities in another country.

Mentor universities typically take care of the development of curricula and quality assurance measures, support the development of infrastructures, and assist in the training of lecturers. They often send their own teaching staff to the foreign institution and engage in fund-raising in their home country. Foreign-backed universities grant their own national degrees. In some cases, the degrees of mentor institutions are granted in addition to national ones. Mentor universities generally receive remuneration from the founders of the university. They normally do not benefit from the revenue generated from tuition fees.

Mentor universities may withdraw once the new institution is fully operational, although they as well as the governments of their countries are usually permanently represented on the boards of foreign-backed universities. The function of rector or 